Prethodno priopćenje UDK 791(045)

791 Bergman, I.

doi: $\underline{10.21464 / \mathrm{fi} 40307}$

Primljeno 3. 11. 2019.

\title{
Janica Tomić
}

Sveučilište u Zagrebu, Filozofski fakultet, Ivana Lučića 3, HR-10000 Zagreb

jtomic@ffzg.hr

\section{Čitati Bergmanov arhiv}

\begin{abstract}
Sažetak
Od godine 2018. dostupan javnosti, arhiv Ingmara Bergmana potaknuo je niz čitanja i revalorizacija, prije svega, tekstualnog dijela njegova opusa. Promišljajući odnos Bergmanovih rukopisa i filmova, u radu se ukazuje na značaj radnih dnevnika (1938. - 2006.) i drugih tekstualnih fragmenata za shvaćanje Bergmanova arhiva, u cjelini, kao umjetnosti. Zaključna analiza filma Pričesnici (Nattvardsgästerna) ilustrira kako isprepleteni dijelovi arhiva pridonose shvaćanju posebno ranije previđenih afektivnih slojeva, nadovezujuci se i na teze o potrebi razrade uvriježenih filozofskih i srodnih pristupa Bergmanovu radu.
\end{abstract}

\section{Ključne riječi}

Ingmar Bergman, arhiv, radni dnevnici, Pričesnici, Nattvardsgästerna

Ovo nije scenarij u klasičnom smislu. Napisao sam nešto najsličnije glavnom glasu koji se nadam uz pomoć svojih suradnika orkestrirati za vrijeme snimanja. Nisam siguran oko raznih stvari, na barem jednom mjestu ne znam baš ništa. Otkrio sam da je tema koju sam odabrao jako široka i da je ovo što sam napisao ili što sam ostavio u konačnom filmu (grozna pomisao!) potpuno proizvoljno. Zato pozivam čitatelja ili gledatelja da se osloni na fantaziju, da slobodno raspolaže materijalom koji stavljam na raspolaganje.

Predgovor scenariju filma Persona (1966.), Bergman 2018b: 29

Ja ja ja ja ja ja ja ja ja ja ja ja ja ja ja ja ja ja ja ja ja ja ja ja ja ja ja ja ja ja ja ja ja osamnaesti ožujak ja ja ja ja do tu sam stigao s pričom kako sam napustio [kazalište] Dramaten i Sthlm i [trg] Karlaplan i odselio se u Hammars jednom zauvijek i napokon ja ja ja ja ja ja ja ja ja. Sada sam ovdje već poprilično dugo i kreativnost mi se stišava i nestaje. Desi se nekad da se odlučim evo sad ćeš početi, sad krećem, ali odluka izblijedi ja ja ja ja ja ja ja ja ja. Ostaje samo velika praznina $i$ veliki nedostatak Ingrid jer Ingrid je sada potpuno odsutna i pitam se da li je to zbog mene ili zato što me Ingrid ostavila zauvijek. Ja ja ja ja ja ja ja ja ja ja ja ja ja. Vježbam ruku: ja ja ja ja. Ne sluša me baš više ja ja ja (...).

Zadnji zapis iz Bergmanova arhiva, vjerojatno iz 2006.

Recentni hrvatski prijevod Bergmanove autobiografije Rođeni $u$ nedjelju (Söndagsbarn, 1991.) odjek je interesa za autorovu književnu produkciju posljednjih godina. Zanimanje je kulminiralo na stogodišnjicu njegova rođenja 2018. godine, kada su izdani brojni ranije neobjavljeni tekstovi tzv. Bergma- 
nova arhiva. Prvenstveno priznat kao redatelj, Bergman je iza sebe ostavio pozamašnu količinu tekstova koji su, u najsustavnijem takvom pothvatu do sada, sažeti u šest tomova sabranih djela i tridesetak pojedinačno objavljenih scenarija ili »filmskih priča (filmberättelser). Taj korpus obuhvaća, uz ranije poznate autobiografije i romane, šezdesetak scenarija njegovih i drugih filmova, drame, stotinjak eseja i članaka, dnevnike rada, tisuće pisama i brojne druge fragmente. ${ }^{1} \mathrm{U}$ šezdesetak godina, Bergman je prešao put od dvadesetogodišnjaka s prvenstvenom ambicijom da postane pisac do redatelja, ali i književnika ili pisca, kako to danas vole isticati bergmanolozi.

Fokus takvog interesa cijele generacije filmologa koji na scenu stupaju od 1980-ih lako je razumljiv pri prvom susretu s ranije neobjavljivanim materijalima. »Institucija Bergman«, kako je posljednjih godina oslikana u nizu dokumentarnih filmova o autoru, ${ }^{2}$ koja je dominirala jednom filmskom kulturom bez obzira na sporadične drukčije glasove Boa Widerberga, Roya Anderssona, Mai Zetterling i drugih koji su se nužno definirali oprekom u odnosu na Bergmana, mladim je autorima bila manje atraktivna od tekstova za koje se svi slažu da su često slobodniji, radikalniji, intimniji i sl. (npr. Holmberg 2018: 410; Koskinen 2002: 49f). Na marginama Bergmanova kanona, iz arhiva će se iskapati npr. scenarij pisan u prozi Riba. Filmska farsa (Fisken. Fars för film, 1951.) koji je fascinirao i »očitim književnim kvalitetama« pa se 1990-ih pojavljuju pionirske obrade korpusa poput biografije Maaret Koskinen $U$ početku bijaše riječ: Ingmar Bergman i njegovi rani književni radovi (I begynnelsen var ordet: Ingmar Bergman och hans tidiga författarskap, 2002). Među mnoštvom recentnijih čitanja arhiva najopsežnija je autorska studija Jana Holmberga Ingmar Bergman, pisac (Författaren Ingmar Bergman, 2018.), čijim se radom provlači ideja da je Bergman bio, prije svega, pisac, a filmovi (gdje postoje) adaptacije njegovih književnih djela (Holmberg 2018: 11, 86).

Holmbergova će se teza problematizirati niže u tekstu, no entuzijazam arhivista ususret budućoj recepciji razumljiv je s obzirom na to da su često najzanimljiviji dijelovi opusa sada prvi puta ugledali svjetlo dana: kraći prozni tekstovi, eseji i fragmenti, među kojima, za početak, izdvajam dnevnike rada (arbetsboken). ${ }^{3}$ Bergmanov dnevnik rada kolaž je apsolutno svega, nerijetko "potpunog nonsensa, pisanja da se pokrene « (o tome kako je spavao, treba li se prebaciti na drugi stol, često o vremenu, čekanju da počne pisati) u kombinaciji s autobiografskim motivima koji se pretapaju u skice i prve nacrte budućih djela (Holmberg 2018: 17f). U jednom će se pasusu tipično izmijeniti (iako nema pravila u rasporedu) izvještaj o vremenu taj dan, opis scene za film koji trenutno radi, pretapanje u prizor iz privatnog života, npr. čežnje za Liv Ullmann, koja ga je ponovo ostavila tu večer da bi otišla na zabavu, i zatim povratak na film:

»Uspjeh filma Na pragu života (Nära livet, 1958) neshvatljiv mi je. Mislim i ja doduše da je to simpatičan komad, ali tako prokleto dobar baš i nije. Zapravo mislim da je i malkice dosadan. Ako ga puste u Cannesu, onda ja stvarno više ništa ne razumijem. Mislim da su malo pretjerano entuzijastični na tom festivalu.« (Bergman 2018a: 75)

I dok se u profesionalnom pisanju borio s riječima, ispovijedajući se u raznim prilikama na tu temu, opisujući stvaranje scenarija kao »mučenje, otpor, nužno zlo $\aleph^{4}$ - »pisati dnevnike je zabavno«, a na pitanje vodi li ih uvijek, odgovara potvrdno, dodajući jedan od autobiografskih lajtmotiva »osim nažalost u jednom periodu života kada se žurio zaraditi dovoljno da uzdržava sve svoje napuštene obitelji« (Holmberg 2018: 22). Zato iako (ili baš zbog toga 
što) ih Bergman nije naročito ozbiljno shvaćao, nazivajući često dnevnik rada i »vježbanjem ruke« (za koje je dosljedno koristio i drukčije bilježnice od onih za profesionalno pisanje - $\mathrm{u}$ dnevniku rada iz 1976. godine stoji: »dosta sam vježbao, sada prelazimo na žuti papir«), dovoljno je reći da je i nastanak scenarija Persone opisao kao jedno takvo »vježbanje ruke« (Holmberg 2018:17-19). ${ }^{5}$

\section{Od djela do teksta}

Od ranije poznatih djela, Slike (Bilder, 1990.) i Laterna magica (1987.) znaju se nazivati Bergmanovim »službenim biografijama«, a potonju je sam autor nazivao svojim »prvim književnim pokušajem « (Holmberg 2018: 101, 162). ${ }^{6}$ Laterna magica djeluje kao skraćena i pročišćena pa i cenzurirana verzija dnevnika rada, iako dijeli s dnevnicima autorske postupke poput pretapanja autobiografskih i drugih fikcija.

Motiv predfilmskog izuma iz naslova, odnos prema roditeljima i druge sablasti iz djetinjstva, strah od smrti, ljubavne veze i njihova manjkavost, otpor prema političkoj klimi i refleksija o umjetnosti - roman je riznica bergmanovskih prizora čije obrade cirkuliraju drugim tekstovima i filmovima. Najočitija je poveznica Lanterne magice s filmom Fanny i Alexander (Fanny och Alexander, 1982.), još jednim rezimeom vlastite autobiografije i filmografije, ali roman će nerijetko i eksplicitno uputiti čitatelja i na druge Bergmanove

Ostatku se arhiva može pristupiti putem internetske stranice Zaklade Ingmar Bergman. Dostupno na: https://www.ingmarbergman. se/en/ingmar-bergman-foundation (pristupljeno 3. 11. 2019.).

2

U najšire diseminiranoj varijanti $u$, na primjer, filmovima redateljice Jane Magnusson poput Bergman - jedna godina, jedan život (Bergman - ett år, ett liv, 2018.) ili televizijskoj seriji Ingmar Bergman - život u četiri čina (Ingmar Bergman - ett liv i fyra akter, 2018. - 2019.), gdje se prezentira, uz brojna svjedočanstva, slika s kraja karijere institucije Bergman koja dominira švedskom kulturom i ne podnosi otpor.

Riječima Rossholma u recentnoj bergmanološkoj studiji: »Analiza ove knjige se znatno udaljava od onoga što se običava nazivati umjetničkim djelom pa čak i pričom. Moglo bi se reći da su najranije skice buduće priče u ovom slučaju njezini najzanimljiviji dijelovi.« (Rossholm 2017: 17)

Redatelj i Bergmanov biograf Vilgot Sjöman komentirao je kako npr. »zna zvučati gotovo svadljivo kad priča o tome kako mrzi pisati« (Holmberg 2018: 20). »Uzdasi, smijeh, stenjanje - nikad nisam čuo da Ingmar Bergman govori o pisanju ikako osim kao o mučenju
(...) nikad kao o užitku, tinjajućoj želji.« (Holmberg 2018: 23)

Za Personu se zna reći da je u odnosu na druge Bergmanove filmove najviše »filozofski« (npr. Arnold Weinstein to tvrdi $\mathrm{u}$ intervjuu u TV-seriji Ingmar Bergman - život u četiri čina), a Bergman je sam izjavio da je u Personi i Kricima i šaputanjima (Viskningar och rop, 1971.) dosegnuo krajnje granice eksperimentirajući u mediju filma. Istovremeno je Personu opisivao kao film potpunog gubitka kontrole, »da sam znao što radim, ne bih to uspio napraviti« (Bergman u Ingmar Bergman - život u četiri čina).

Treba dodati da su na skandinavskim, ali i na engleskom i drugim jezicima, Bergmanova djela »češće objavljivana nego što to mnogi znaju« (Burman 2018: 299), što ilustriraju i predgovori recentnih sabranih djela koje je izdavač povjerio šarolikoj europskoj postavi kulturnjaka (od norveškog pisca Karla Ovea Knausgårda, danske književnice Dorthe Nors i francuske autorice Nine Bouraou do estonskog scenarista i bergmanologa Christe Burmana) koji svjedoče o tradiciji čitanja Bergmanovih tekstova kao npr. intelektualne podrške u stvaralačkom procesu, upisujući ga u kanone življene kulture i izvan granice filmske umjetnosti. 
filmove. Tako, na primjer, epizodu u kojoj bježi u Pariz s budućom suprugom Gun Grut komentira na sljedeći način:

»Za dalje podatke upućujem na ljubavničku sobu u Tišini (Tystnaden, 1963.).« (Bergman 1990: 171)

»Koga zanima što se dalje zbilo, može pogledati treći dio Prizora iz bračnog života (Scener ur ett äktenskap, 1973.)« (Bergman 1990: 170)

Drugom će prilikom za istu scenu u Prizorima reći da je utemeljena na događajima aktualnim u vrijeme snimanja te serije, raspadu braka Ingrid von Rosen, dodajući toj fikciji još jedan sloj ili »repeticiju na temu Bergman«. Koskinen (2002: 70) zaključuje kako je u Bergmanovu arhivu dobro poznata autobiografska pozadina svećeničkog doma i kasnijih provodnih tema služila kao plodno tlo za fantaziju, koju su jednako potpaljivali književni idoli u žanru obiteljske drame poput Strindberga. Lanternu magicu uvodi jedna takva strindbergovska laž:

»Kad sam se rodio, srpnja 1918., moja je majka bolovala od španjolke, a ja sam se rodio u tako lošem stanju da su me na brzu ruku u bolnici još pokrstili.« (Bergman 1990: 5)

Budući da niti je zbiljska majka bolovala od španjolske gripe, niti je mali Ingmar kršten pod prijetnjom smrti, prva se rečenica Lanterne smatra primjerom posvete Strindbergovim dramatizacijama vlastitog djetinjstva ${ }^{7}$ (Holmberg 2018: 43, 169).

S podtekstom Stindbergovih fikcionaliziranih autobiografija veže se i romaneskna trilogija posvećena turbulentnom braku Bergmanovih roditelja: Najbolje namjere (Den goda viljan, 1991), Razgovori u četiri oka (Enskilda samtal, 1996.) i Rođeni u nedjelju. Tekstovi su žanrovski neodredivi, pri čemu etikete variraju na skali između fikcije i fakcije: osim što ih arhiv klasificira kao romane, žive u raznim kontekstima i kao »biografije«, »biografski romani« ili »memoari«. No Rođeni u nedjelju, prije svega, autobiografska je fikcija jer opisuje scene iz djetinjstva dječaka Pua (»pseudonim za Ingmara kojeg su zvali Putte«, Holmberg 2018: 206), zaključno s podužom sekvencom gotovo preslikanom s kraja Lanterne magice: odlazak na propovijed u obližnju crkvu i povratak biciklom kući kao rijedak trenutak bliskosti dječaka s ocem.

Pseudonimi su kroz cijeli opus omiljen Bergmanov postupak, počevši od ranih radova gdje se spomenuti repertoar autobiografskih lajtmotiva pripisuje fiktivnim protagonistima, a nekolicina se »alter-ega « provlači brojnim djelima (npr. »Kasper« ili »Jack«). No još je zanimljivija šira kategorija »autofikcija (jagfiktioner) koju bismo u proširenom značenju mogli upotrijebiti i za spomenuta djela poput Lanterne magice i Bergmanov arhiv u cjelini. Autofikcija je u sabranim djelima oznaka za heterogeni skup tekstova; naći će se tu u pravilu kraći fragmenti s naslovima poput Šest pitanja za Ingmara Bergmana (Sex frågor till Ingmar Bergman, 1956.) ili borgesovsko uslojavanje fiktivnog autora pod naslovom Ingmarov autoportret... koji je napisao on sam (Ingmars självporträtt... skrivet av honom själv, 1957.). U autofikcije se ubrajaju i brojni autointervjui poput Ingmar Bergman intervjuira sam sebe ususret premijeri Ljeta s Monikom (Ingmar Bergman intervjuar sig själv inför premiären på Sommaren med Monika, 1953.). Riječ je o fiktivnim intervjuima koje je Bergman vodio sam sa sobom u raznim ulogama, od 1960-ih nadalje koristeći i pseudonime pod kojima su tekstovi i objavljivani. Francuski filmski kritičar i žestoki kritičar Bergmana »Ernst Riffe« najpoznatiji je među njima, ali rado bi utjelovio i personu danskog filmologa »Madsa Mandrupa Nielsena« ili finske novinarke i kulturne antropologinje »Anne Salander«. Autointervju 
je uglavnom medij za satiričke komentare na dominantne stavove o (posebno Bergmanovoj) umjetnosti i politici, ali nerijetko i nešto što djeluje kao iskrena samokritičnost i introspekcija. Zajednička je crta autofikcija, tvrde tumači, »autoironija kojom Bergman istovremeno pokazuje da je svjestan - i stvara svoje slike za koje će uhvatiti mediji, jedan za drugim« (Burman 2018: 303).

Među djela ranije poznata međunarodnoj publici spadaju i Bergmanovi scenariji, poput tri teksta tzv. Filmske trilogije (En filmtrilogi, 1963.). Na valu auteurizma i interesa za scenarije redatelja poput Fellinija i hibridne forme poput ciné-romana Marguerite Duras i Alaina Resnaisa, američke su se izdavačke kuće, uz dosta napora i vala pozitivnih kritika, ${ }^{8}$ prve uspjele domoći prava. Bergman početno nije bio sklon knjiškim izdanjima svojih scenarija, posebno ne na materinjem švedskom, pa je prvi primjerak stigao uz predgovor u kojem je Bergman citirao svoju poznatu definiciju scenarija koji je »uvijek poluproizvod, blijeda zrcalna slika« filmske umjetnosti (cit. u Holmberg 2018: 184). Nakon Persone će, međutim, redovito objavljivati scenarije svojih filmova, dodajući im i predgovore. Od tog će perioda, primijetit će mnogi, scenariji postajati sve manje konvencionalni, odnosno sve »literarniji«. Mikael Timm je, na primjer, zaključio da je

»... scenarist Bergman u većoj mjeri književnik nego zanatlija. Njegovi se scenariji uvijek mogu čitati kao priče, pisani su kao novele, bez podjela na scene. Oslikavao je atmosferu i opisivao stvari koje se ne mogu predočiti u slici, poput mirisa.« (cit. u Holmberg 2018: 105)

I Birgitta Steene primijetila je da su scenariji puni književnih digresija koje su od malo ili nikakve koristi producentima, snimateljima, glumcima ili drugoj ciljanoj publici - jedva i redatelju samom. ${ }^{9}$ U novije se vrijeme Ana-Sofia Rossholm komparatistički bavila scenarijima i zaključila da je »Bergmanov scenarij sličniji književnom tekstu od većine ostalih i bitno je drukčiji od klasičnog detaljnog plana«, nadovezujući se i na ranija tumačenja »otvorenosti« Bergmanovih scenarija kao temelja za slobodu improvizacije glumaca i ostatka filmske ekipe (Rossholm 2017: 100-112). Scenarij Persone uspoređivat će i s poezijom, a opisi budućih dijelova npr. prologa filma često će značajno odudarati od konačnih prizora filma:

»U bijelo-bijelom pojavljuju se obrisi oblaka, ne odraza na vodi, ne vjerojatno je to bio oblak, ne stablo s ogromnom krošnjom, ne mjesečev krajolik.

Buka [koja prati slike iz projektora] se pojačava i zavija i cijele riječi (nesuvisle i daleke) počinju izranjati kao sjene riba u dubokoj vodi.

U autobiografijama poput Sluškinjinog sina (Tjänstekvinnans son, 1886.), Strindberg izmišlja npr. klasni jaz između roditelja iz naslova djela koja motivira njihov sukob, odnosno njegovo navodno tragično djetinjstvo. $\mathrm{Na}$ sličnom je tragu fikcionalizacije djetinjstva $\mathrm{i}$ nedostatak lika židovskog dječaka u Bergmanovim (auto)biografskim zapisima, djeteta koje su Bergmanovi posvojili za vrijeme II. svjetskog rata i tretirali kao trećeg sina - biografska crtica koja bi proturječila narativima o očevoj strogosti, nacizmu i općeobiteljskom nedostatku ljubavi i filantropije.

8

Usporedbi s npr. Tennesseejem Williamsom ili Edwardom Albeejem. Pomogla je zasigurno i činjenica da Bergman nije imao naročit respekt prema američkoj kulturi, o čemu svjedoči niz anegdota, npr. o tome kako navodno nije znao ni želio naučiti kako se pravilno piše Hollywood (Rossholm 2017: 61).

9

Kao jedan od primjera daje uvod u Sedmi pečat gdje vitez »gleda ravno u jutarnje sunce koje izranja iz mutnog mora poput nadute umiruće ribe« (cit. u Holmberg 2018: 105), dok Birgitta Ingemansson npr. piše o Bergmanovim scenarijima kao prepunim za žanr netipičnih olfaktornih detalja (cit. u Koskinen 2010: 100-103). 
Nema oblaka, nema brda, nema stabla s gustom krošnjom, samo lice s pogledom uprtim u gledatelja. Lice sestre Alme.« (cit. u Holmberg 2018: 114-115)

Drugim riječima, s vremenom će Bergman u rastućoj slobodi od filmske industrije pisati u sve slobodnijoj formi, posebno u usporedbi sa znatno konvencionalnijim scenarijima iz 1940-ih i 1950-ih. Za scenarij filma Fanny $i$ Alexander s kraja redateljske karijere reći će se da je »najbliže romanu od svega što je Bergman do tada napisao«, odnosno da je »prepun opisa koji se ne daju direktno ili bez teškoća prevesti u slike, već žive vlastitim životom u dimenziji pisane riječi« (cit. u Homberg 2018: 120; Koskinen 2010: 103).

Konačno, među ranije kanoniziranim su dijelovima njegova opusa eseji kojima je ostvario najveći uspjeh kao pisac. »Zmijska koža« (»Ormskinnet«, 1965.) međunarodno je najpoznatiji primjer, ali i pasusi drugih eseja poput »Svaki film je moj posljednji film« (»Varje film är min sista film«, 1959.), »Snimati film« (»Det att göra film«, 1954.) itd. pojavljivat će se u brojnim izdanjima i naveliko citirati. S jedne strane, velik je dio eseja posvećen filmu, pa ulaze u korpus Bergmanovih autopoetizacija koje su definirale recepciju njegovih filmova. S druge strane, tvrdit će se s pravom da forma eseja najbolje odgovara bergmanovskom pismu jer, uz argumentacije na širok spektar tema »njegov slikovit jezik zahtijeva konstante ilustracije situacijama, prostornim opisima« (Burman 2018: 299).

»U drugim književnim žanrovima često je na oprezu, vođen konvencijama ili drugim vanjskim okolnostima. Eseji su s druge strane slobodni, otvoreni i začuđujuće puni užitka i kad je najozbiljniji. Kao da ne može ni sam od sebe sakriti radost pisanja.« (Holmberg 2018: 64)

\section{Riječi, riječi, riječi}

Jedna je od provodnih tema Bergmanovih eseja odnos prema pisanju, konkretnije poteškoća prevođenja imaginarnih slika u riječi koje izmiču (i obratno, posebno kada je riječ o filmskim adaptacijama književnih tekstova). U eseju »Snimati film«, segment naslovljen »Često započne slikom« (»Det börjar ofta som en bild«) obrađuje sveprisutan motiv takvih »specifičnih slika ili osjećaja kojima započinju moji filmovi« i oko kojih se nižu druge slike i »nastaju grude iz pahulja snijega« (cit. u Singer 2009: x). Fotografija dviju žena koje uspoređuju ruke, na primjer, prvi je trag teksta i filma Persona koji se pojavljuje u radnom dnevniku.

Poteškoće nastaju kada treba verbalizirati.

»Ne vjerujem riječima - nikada im nisam ni vjerovao. Nema ih gotovo nikad pri ruci kad ih trebam, sakriju se u kutu ili lete u krugovima ispod stropa kao dosadne muhe.« (Bergman 2018b: 29)

Odnosno, u nešto dramatičnijoj varijanti:

»Strah pred početak. Strah od riječi. Nemogućnost da presadim ove slike koje su tako kristalno jasne u razumljive riječi, koje postanu tako besmislene i ravnodušne. Lijenost i banalnost. Bolest pisanja dijaloga. Riječi koje se zovu jer, te, zato. (...) I tolika moja mržnja prema tom umrtvljujućem, destruktivnom, opasnom, ali nužnom procesu.« (cit. u Holmberg 2018: 39)

Uz ovu vrstu osobnih ispovijesti s kojima se dijelom i pretapa, razrađuje i srodnu temu kontrasta institucija filma i književnosti. Često navođeni dijelovi eseja »Svaki film je moj posljednji« ilustrativni su za temeljne opreke oko kojeg se gradi ta dihotomija: visoko - nisko, institucionalno - komercijalno i, ono najzanimljivije, intelektualno - emotivno. 
»Film nema veze s književnošću. (...) Pročitana riječ apsorbira se svjesnim, voljnim činom i uz pomoć intelekta, tek se onda postepeno aktiviraju naša imaginacija i osjećaji. U kinematografiji je proces drugačiji. Za vrijeme filmske projekcije svjesni smo da je iluzija priređena za nas i opuštamo volju i intelekt. Oslobađamo put prema imaginaciji. Slijed slika djeluje prvo na naše osjećaje bez posredstva intelekta. (...) Jedini razlog zašto svi smatraju da su sposobni govoriti o filmu taj je što se film ne uspijeva uzdići kao umjetnička forma, nedostaje mu jasna nomenklatura, zrelost i status drugih umjetnosti, vezuje se za ekonomske okolnosti i primitivno djelovanje na emocije. Sve to dovodi do prezira s kojim se često gleda na film, sumnjičavosti prema izravnosti filmskog izričaja, zbog čega se svatko smatra kompetentnim da govori što god mu padne na pamet u kojem god kontekstu o filmskoj umjetnosti. Osobno nisam nikada imao ambicija da postanem pisac. Ne želim pisati romane, novele, eseje, biografije ili sastavke na razne teme. $\mathrm{Ne}$ želim pisati čak ni kazališne tekstove. Želim praviti filmove od stanja, uzbuđenja, slika, ritmova i likova koje nosim sa sobom i koje su na ovaj ili onaj način za mene aktualni. Film je moje sredstvo izražavanja, ne pisana riječ. Film i njegov kompliciran proces nastanka su moj način komunikacije s ljudima oko mene. Ponižavajuće mi je kada se moj opus tretira kao knjiga kada je to film.« (Bergman 2018b: 65)

Književno polje ponekad dobiva i pozitivnije konotacije, kada se, recimo, razrađuje opreka između književnika koji piše za kritičara (i koji može prodati svega nekolicinu primjeraka knjige i ostvariti uspjeh), za razliku od filmskog i kazališnog djela koje se mora svidjeti masovnijoj publici da bi postojalo nakon premijere. Moguće je iz takvih pasusa iščitati i frustraciju filmaša koji, bez obzira na zavidne socijalne vještine, neku od najžešće satire ispoljava za vrijeme filmskih festivala i prema filmskom establišmentu i nasuprot njima postavlja izolaciju kao preduvjet kreativnosti, priželjkujući i sofisticiraniju komunikaciju od reakcija filmske publike i kritike. No argument se ubrzo obrće u brojnim afirmativnim pasusima o filmu kao atrakciji npr. eseja »Mi smo cirkus! ( (»Vi är cirkus!«, 1953.) koji slavi figuru mađioničara, sajmišnog zabavljača Mélièsa kao uzora modernim nasljednicima filmskog stroja i njegove jedinstvene moći djelovanja na publiku:

»Stvar je u tome da mi bolujemo od teškog kompleksa manje literarne vrijednosti. To je tako blesavo, ponižavajuće, ludo.« (Bergman 2018b: 33f)

Stoga su izjave poput one da se bavi filmom, a ne književnošću jer »ja nemam ni tu finu intelektualnu opremu« (cit. u Holmberg 2018: 40) još očitije ironične u kontekstu brojnih čak euforičnih zapisa o procesu stvaranja i gledanja filma gdje intelektualna dimenzija ili »filozofske ideje nisu za njega ni u suštini kreativnog čina niti iskustva umjetnosti (filma)« (Steene 2008: 222). To visceralno i afektivno djelovanje, blisko npr. Kracauerovoj teoriji učinaka filmskog medija, u fokusu je značenjskog sklopa »film« za Bergmana, a dodaje mu se i analogija s filmskom glazbom ili apstraktnije ritmom kao lajtmotivom u Bergmanovim autopoetizacijama. ${ }^{10}$

»Film kao san, film kao glazba. Nijedna se vrsta umjetnosti osim filma ne probija pokraj naše svijesti o svakodnevnom tako izravno prema našim osjećajima, duboko u sumračne prostore duše. Mali nedostatak u našem vidnom živcu, šok-efekt: dvadeset i četiri osvijetljena četverokuta u sekundi, među njima tama. Kad za montažnim stolom okrećem filmsku vrpcu, četverokut za četverokutom, iznova doživljavam onaj vrtoglavi osjećaj čarobnosti iz djetinjstva (...).« (Bergman 1990: 79)

10

»Često doživljavam film ili dramu kao da je riječ o glazbi«, jedna je od takvih autopoetskih izjava na koje se redovito nadovezuju tumači, ističući i ritam kao ključan element: »tretman filma kao da je riječ o glazbenom komadu vjerojatno ulazi u Bergmanov recept za stvaranje filmove« (Staiger 2008: 95). 
Bergmanov odnos prema (instituciji) književnosti istovremeno varira, ovisno o kritici njegovih djela koja je u ranijim fazama izrazito nenaklonjena. Izdavači su odbili njegov navodno najozbiljniji književni pokušaj, a kritičari su bili jednoglasni u ocjeni da je mladi Bergman

»... dobar, čak i nadaren režiser, ali loš pisac. Pod pojmom 'loš' razumijevalo se: napuhan, na razini gimnazijalca, pubertetski, naporan, sentimentalan.« (Bergman 1990: 163)

Na to će kao tada već poznati redatelj Bergman retrospektivno odgovoriti:

»... put prema novelama, romanima i dramama bio je hermetički zatvoren, i na tome sam im zahvalan.« (cit. u Holmberg 2018: 38f)

U susretu s tim ranim radovima u izvorniku, postaje očito da je riječ o opravdanim kritikama pretjerano kićenog stila i formulaičnosti, u fragmentima koji znaju djelovati poput srednjoškolskih sastavaka o npr. veličini švedske književnice Selme Lagerlöf. Holmberg s pravom komentira da bi mu savjet s radionice pisanja bio da ne misli toliko, već da samo piše - »da vježba ruku« (Holmberg 2018: 17). Istodobno je riječ o stadiju u razvoju vlastitog pisma, postupnom procesu pojednostavljenja Bergmanova stila prema minimalizmu tekstova i filmova od 1960-ih. ${ }^{11}$ Slična se razvojna putanja nazire i tijekom čitanja knjige Fanny i Alexander, gdje užitak u tekstu raste kako ritam ubrzava do kulminacije pred kraj romana, pretapajući prizore iz filmova, biografskih slika djetinjstva, drama, ljubavnih odnosa, roditeljskog braka itd., pročišćenih od suvišnih komentara. Zanimljivo je da će sam Bergman taj svoj zreli, razrađen stil pisanja definirati kao pisanje koje je izvježbao u posljednjih pedesetak godina - »u filmskoj formi« (cit. u Holmberg 2018: 122).

Literarni scenariji, filmični tekstovi - recentne se revalorizacije Bergmanova opusa kao »književnog « čine dodatno problematičnima uzmemo li u obzir da umjetnost u bergmanovskoj idealnoj projekciji opire intelektualnoj raščlambi, konvencijama i klasifikacijama. Kako gasi sinestetički komentar iz radnih dnevnika nastao za vrijeme snimanja filma Tišina:

»Čini mi se da imam jedno uho više utopljeno u tijelo, jedan nos u utrobi, još jedno oko koje zuri u mozak.« (cit. u Koskinen 2010: 16)

\section{Zimsko svjetlo}

»Povrh svega, pisao je o svom pisanju - zato je imao radne dnevnike.« (Holmberg 2018: 16)

Šezdesetak sačuvanih radnih dnevnika nastajalih u kontinuitetu od 1938. do 2001. već su ranije izdvajane u Bergmanovu opusu, kao svojevrsni l'avanttexte kao metatekst (Rossholm 2017: 27). U Slikama, utjecajnim zapisima o svojoj povijesti filma, Bergman se vraćao prije svega arhivu radnih dnevnika koje parafrazira i pripisuje im »središnju ulogu u stvaralačkom procesu « (cit. u Rosshlom 2017: 56, 108). S obzirom na to da je privatne dnevnike vodio tek od pedesete godine, a i taj dio arhiva ostaje zatvoren za javnost do 2055 ., rijetko sustavno očuvan korpus radno-dnevničkih zapisa sada dolazi u fokus filmografije i biografije:

»U radne dnevnike Ingmara Bergmana stane, čini se, njegov cijeli život. I mnogo tog života transformira se ubrzo u gotove tekstove (...). $\ll^{12}$ (Holmberg 2017: 21)

Kako ti zapisi (re)definiraju Bergmanov opus možemo ilustrirati na primjeru filma Pričesnici, koji kroz godine čitanja i sam dolazi u središte Bergmanova arhiva. Dvanaestominutna uvodna sekvenca mise na kojoj nitko od šačice 
likova nije prisutan duhom uvodi Bergmanov najradikalnije minimalistički film, »čija bi se radnja mogla opisati kao niz pokušaja razgovora« (Zern 2018: 133). »Božja šutnja«, kako glasi neformalan naziv trilogije koju čine filmovi Kroz tamno ogledalo, Pričesnici i Tišina, prevodi se u nemogućnost protagonista, pastora Thomasa, da komunicira s pričesnikom koji ga traži utjehu kao i nedostatak ljubavi u vezi s učiteljicom Martom. To je ukratko sadržaj ove komorne drame koja se najčešće opisuje pojmovima »ogoljelost« i »jednostavnost«, a koja označava spomenutu stilsku prekretnicu reduciranom izrazu u djelima od 1960-ih, lišenih »baroknih specijalnih efekata«, »svih onih spektakularnijih elemenata kojima je postigao najveći uspjeh kod kritike i publike u Sedmom pečatu ili Divljim jagodama « ${ }^{13}$ (Sjöman 1978: 134). Emocionalna izolacija protagonista podcrtana je reduciranim dijalozima i tišinom koju je Bergman u pojedinim trenucima težio postići eliminacijom čak i prirodnih zvukova na filmskom setu. Snimatelj Sven Nykvist isticao je ovaj projekt kao jedan od zahtjevnijih eksperimenata osvjetljenjem, koje je, kako to biva sa zimskim svjetlom, škrto podržavalo iluzije »tračaka svjetlosti u usamljenosti« (Sjöman 1978: 123f). Ravnomjerno sivilo neba i prostora na zemlji stvara dojam monokromije i brisanja linije horizonta, eliminirajući po jednom tumačenju i »svaku sugestiju metafizičke dvojnosti, što služi kao pozadina stravične samoće pričesnika, kako u crkvi tako i u društvu izvan nje« (Singer 2009: 125)

Iako loše primljen od suvremenika, ovaj »potpuno ogoljeli film, bez ornamenata, kroz desetljeća otkako je napravljen ne prestaje rasti u očima publike i doimati se sve ljepši« (npr. Zern 2018: 174). Naknadnoj kanonizaciji pridonio je i sam Bergman, izdvajajući Pričesnike retrospektivno u raznim fazama života, ${ }^{14}$ a i šira će se recepcija gotovo opsesivno vraćati filmu. Čini se da ne postoji posebno među recentnijim naslovima monografija koja neće ilustrirati bergmanovske postupke na primjeru Pričesnika, a povijest biografskih tekstova preispisuje taj jedan među desecima njegovih filmova, počevši

11

Sjöman prizor iz filma Kroz tamno ogledalo (Såsom i en spegel, 1961.), u kojem lik uči pisati pojednostavljujući svoj izraz, čisteći tekst od suvišne melodramatike i sl., naziva »sažetkom Bergmanova vlastitog stilskog razvoja«. »DAVID (čita): Ona je išla prema njemu zadihana od iščekivanja, rumena od oštrog vjetra (uzdiše)... (...) Ona je išla prema njemu zadihana od iščekivanja... (...) Maše glavom i naginje se nad listom papira, ispisuje crvenim slovima sljedeće: Ona mu je trčeći dolazila $u$ susret. Zatim uzdiše, odmahuje glavom, križa zapisano i odlučno zapisuje: »Sreli su se na obali.« (cit. u Koskinen 2019: 84-85)

\section{2}

Istu kvalitete prepoznate su još u Slikama (u engleskom prijevodu Images: My Life in Film): »Očekivali bismo priču o redateljevom životu tijekom snimanja filmova - njegovim iskustvima na setu i izvan njega s glumcima, producentima i drugim profesionalcima, zajedno s brojnim problemima koji se javljaju u procesu nastanka filma. To je cjelovito značenje Renoirove knjige istog naslova
[Ma vie et mes films, 1974.]. No u Bergmanovu slučaju, vjerujem da je ispravno čitanje podnaslova kao znaka prisutnosti i estetskog značaja vlastitog života za njegove filmove (...).« (Singer 2009: 7)

13

Sjöman zaključuje kako je, radeći na ideji Pričesnika, Bergman izvukao materijal iz književne tradicije (moraliteta) u drugu (strindbergovska ispovjedna drama). »Pomak se kretao od crkvene stilizacije do svakodnevnog realizma.« (Sjöman 1978: 43) Zahtjevnost takve jednostavnosti filma Bergman je $\mathrm{u}$ analogiji s glazbom opisao kao »jedan ton«, »jedan emocionalni naboj od početka do kraja (...) lakše je kada imaš više emocionalnih razina da izgradiš ritam, kontrast « (cit. u Singer 2009: 62).

»Zadovoljstvo je vidjeti Pričesnike nakon četvrt stoljeća. Konstatiram da se ništa nije pohabalo i ništa nije polomilo.« (Bergman 1996: 157) $\mathrm{U}$ jednom ranijem intervjuu kaže: »Mi- 
od TV-serije Ingmar Bergman pravi film (Ingmar Bergman gör en film, 1963.) i knjige L136: Dnevniks Ingmarom Bergmanom (L136: dagbok med Ingmar Bergman, 1963.) Vilgota Sjömana, do biografije Redatelj (Regissören, 2006.) Alexandra Ahndorila itd. Ako je Bergmanov život intertekst, Pričesnici su neupitna ilustracija često navođene teze da su autobiografije manje utjecajne od fikcionalnih filmova slične tematike (npr. Flower 1989: 333).

Prva asocijacija su biografije Bergmanova oca, posebno Najbolje namjere, ali i drugi fragmenti gdje se aludira na obiteljska previranja, kao i krizu svećeničkog poziva Bergmanova oca Erika. Upadljiva je paralela s tzv. epizodom u Forsbacki (u Najboljim namjerama, gdje se većim dijelom i opisuje, naziva se Forsbodom, pri kraju avanture i paklom), izoliranim selom na sjeveru Švedske kamo Erik odlazi na svojevrsnu filantropsku misiju u roli seoskog svećenika. Povevši i mladu suprugu Anu, kojoj lokalna uskogrudnost i surova svakodnevica još teže padaju u kontrastu s visokim društvom Stockholma, period u Forsbacki i odluka da je napuste označava prekretnicu u nepovratnoj propasti pastorova braka i vjere.

S druge strane, Pričesnici su među Bergmanovim scenarijima koje je pisao dijelom u trećem, a dijelom u prvom licu, a zapisi o filmu u radnim dnevnicima u fokus stavljaju jedno bergmanovsko »'Ja' u centru priče, cijelo vrijeme u borbi sam sa sobom « (Bergman 2018a: 108). Ne čude stoga i brojna čitanja autobiografskog sloja filma, poput paralela između svećenika i bergmanovske figure umjetnika u krizi. Dokumentarac Ingmar Bergman pravi film npr. snima Bergmana kako na filmskom setu Pričesnika s oltara daje upute glumcima, dok glas naratora prepričava poznati fragment njegova eseja posvećen Katedrali u Chartresu. Na tragu Ruskinove refleksije o gotskom stilu, Bergman suprotstavlja ideal anonimne kolektivne umjetnosti srednjeg vijeka i organsku vezu radnika i zajednice sa suvremenom umjetnošću koja je isključivo individualna i solipsistička. Poput zmijske kože, umjetnost je »kruta jer je mrtva, izjedena, lišena svog otrova«, puna umjetnika mrava kakav je i on sam, pogoni ih radoznalost iako »nema tu moć niti mogućnost da utiče na razvoj našeg vremena« (Bergman 1996: 32-34). Ambivalentan stav prema svrsi umjetnosti, figure umjetnika koji parazitiraju na tuđim iskustvima (npr. umjetnici kao vampiri koje su Susan Sontag i drugi nalazili u filmovima poput Persone, Kroz tamno ogledalo itd.), a zauzvrat ne može doprijeti do publike, konstanta su kod Bergmana. Godard je, recimo, primijetio da »svaki Bergmanov film iznenadi u odnosu na prethodni« (Godard 1986: 78), a ta sposobnost reinvencije ili učenje filmskog pisma, Bergmanov je konstantan generator anksioznosti. U Lanterni magici, npr., opisuje san koji ga progoni, noćnu moru da dolazi na filmski set i ne zna kako se pravi film, predlaže suradnicima da improviziraju, da pomiču kameru kao Tarkovski, uvjerava ih da snima filmove već četrdeset i pet godina, ali sada traži nova rješenja (Bergman 1990: 182-183). U ovom se periodu umjetničke krize umnažaju, pa će 1960-ih Bergman pisati kako se osjeća kao anakronizam ili dinosaur, u odnosu na estetiku novih generacija filmaša (Bergman 1996: 9). U pozadini je tih previranja najradikalnija estetska metamorfoza u karijeri koju označavaju filmovi trilogije u Bergmanovoj filmografiji, koje je sam opisao kao »rad zavezanih ruku« ili »apstiniranje od vlastite virtuoznosti« pisanja dijaloga (Koskinen 2010: 40-41). Božja je šutnja, drugim riječima, među ostalim implicirala i prijelaz s »literarnih na filmične filmove«, odnosno »pomak prema vizualnom izrazu, $u$ kontrastu s naglašeno rječitim filmovima prve polovice 
Bergmanove karijere« (Steene 2008: 224). Tektonske promjene u vlastitom izričaju reflektiraju i radni dnevnici pisani u to doba:

»... pitanje je:

Kako dobiti jednostavnu i čistu formu?

Kako postići da to bude film, a ne svinjarija?

Kako da bude toliko zabavan da ga ljudi požele gledati?

Kako se kvragu pravi film?« (Bergman 2018a: 75)

Sjömanova knjiga koja prati snimanje Pričesnika u poglavlju pod naslovom »Usamljenost redatelja« opisuje izolaciju autora koji još i uspijeva izraziti intelektualne dimenzije riječima, ali ne i emocionalne:

» ... koje postaju plošne i jednodimenzionalne kad ih se prevodi u riječi - a i autor ih sam nije u potpunosti svjestan. Zato tolika zahvalnost kada ga netko napokon razumije. Tračak svjetlosti u usamljenosti.« (Sjöman 1978: 123)

Time istovremeno među prvima uočava, odnosno dovoljno pažljivo parafrazira Bergmana, da zamjećuje kako sami intelektualni slojevi na koje se fokusirala kritika ne mogu u potpunosti objasniti atrakciju Pričesnika za generacije gledatelja.

Bergman je na naslovnicama, marginama i drugdje po radnim dnevnicima dodavao kroki-crtež malog opscenog đavla koji je danas lajtmotiv grafičkih obrada knjiga o autoru. Taj burleskni motiv može, s jedne strane, uputiti na parodijsku dimenziju filma, posebno »religije kao lošeg teatra« (Donner 2009: 214), prebacujući fokus na svjetovnije i prizemnije teme. ${ }^{15}$ Motiv je simptomatičan za Bergmanovu tekstualnu produkciju u cjelini, a posebno skice neobjavljivane za života koje su znatno eksplicitnije od Bergmanovih filmova »gdje su nasilje, seks i brutalnost prikazivani neizravno« (Rossholm 2017: 18). U kontrastu s filmskim medijem, koji je u većoj mjeri podložan cenzuri (a švedska je cenzura, iako slobodoumna u pitanjima seksualnosti, bila notorno stroga kada je riječ o nasilnim scenama), neobjavljivane ranije verzije scenarija i posebno radni dnevnici bacaju novo svjetlo na slojeve za koje se danas zna da su zanemareni u Bergmanovim filmovima, a na koje je sam često ukazivao, poput nasilja.

»Medij filma kao stvoren je za prikaz destruktivnih činova, činova nasilja. To je jedna od savršeno legitimnih funkcija filma: da ritualizira nasilje.« (cit. u Singer 2009: 142)

Rijetko se u filmološkim osvrtima nađu komentari na npr. ubačene dokumentarne prizore ratnih i drugih stradanja u Personi, odnosno na nasilje film-

slim da sam napravio samo jedan film koji mi se stvarno sviđa i to su Pričesnici. To je jedin film u kojem imam osjećaj da sam počeo na jednom, završio na drugom mjestu i da mi je sve po putu išlo na ruku. Sve je točno onako kako bih mogao poželjeti, u svakoj sekundi filma.« (cit. u Simon 1978: 78) Iako su suvremenici film smatrali, prije svega, dosadnim (lajtmotiv u kritikama), kontrast s naknadnom recepcijom može ilustrirati npr. posthumni sud u časopisu Guardian gdje su Pričesnici proglašeni Bergmanovim najboljim filmom.

15

Iako svećenika glumi Bergmanov ponajbolji komičar Gunnar Björnstrand, humor je promakao većini čitanja djela, s iznimkom npr. Robina Wooda, koji od spomenute uvodne sekvence mise (»tour-de-force ekspozicije«) uočava notu apsurda religijskih i drugih rituala pa cijeli film s pravom smješta na rub tragikomičnog (Wood 1979: 109f). U svjetlu toga, primjećuje i otuđenje koje i učiteljica i drugi marginalni likovi drame osjećaju u svojem pozivu pa svećenikova previranja vidi tek kao dio šireg problema krize solidarnosti i javnog dobra, dakle, vjere u bergmanovski uzemljenoj varijanti ljubavi i altruizma. 
skog medija kao takvog (kao u npr. provodnoj temi scena koje rekapituliraju povijest filma u uvodnoj sekvenci Persone). No Pričesnici sadrže moguće i najbrutalniju scenu Bergmanova opusa, barem ako je suditi po gotovo prisilnom ponavljanju kojim se recepcija vraća na tzv. scenu u školi, kao »jednu od najintenzivnijih « ili »najbolnijih i najružnijih u cijelom Bergmanovu djelu« (Wood 1979: 118; Macnab 2009: 161; Koskinen 2015: 42 itd.). Često i bez ukotvljenja u tumačenja filma, scena funkcionira kao atrakcija popularnim koliko i znanstvenim čitanjima Bergmana, iako je riječ (ili baš zato što je u Bergmanovu slučaju riječ) o verbalnom nasilju svećenika Thomasa nad učiteljicom Martom koja mu prethodno izjavljuje ljubav:

»THOMAS: Umoran sam od tvoje pažnje... tvojih gluposti... tvojih korisnih savjeta... tvojih malih svijećnjaka i stolnjaka. Sit sam tvoje kratkovidnosti... tvojih nezgrapnih ruku... tvojih strahova... tvog straha kada mi pokazuješ nježnost. Prisiljavaš da se bavim tvojim fizičkim stanjima, tvojom lošom probavom, tvojim osipom, tvojom menstruacijom, tvojim promrzlim obrazom (...).« (cit. u Zern 2018: 134-135)

Iako će se motiv samoće pojavljivati tijekom cijele karijere, ovom periodu postaje akutan, pa zbirku radnih dnevnika tog perioda uvodi rečenica (1955. - 1974.):

$»$ Počinjem pisati o Akrobatima danas, 16. lipnja. Toplo je subotnje popodne i zaista sam jako usamljen.« (Bergman 2018a: 15)

Kada stigne do Pričesnika, piše »dragi gospodine Bergmane, smislio sam radnju filma « $i$ to je usamljenost, odnosno u ponovo jedna slika kojom započinje film, ovoga puta svećenika u crkvi u kojoj je još samo žena koja uređuje cvijeće, i na kraju opisa zaključak:

»Razilaze se, ona odlazi i ostavlja ga samog, ostavlja ga samog ostavlja ga samog.« (Bergman 2018a: 111)

Paralelno s uzemljenjem božje šutnje i u intimnu sferu, vidi se i naznaka drugog »ja« ili subjekta ženskog lika, a kako napreduje opis filma u radnim dnevnicima, fokus sve eksplicitnije prelazi sa svećenika na, kako je to Robin Wood još primijetio, »enigmu Marte « (Wood 1979: 111). Za razliku od dominantnih tumačenja Marte kao pomoćnika ili svojevrsnog iskupitelja, isusovske figure ili preslike idealne žene, Wood primjećuje da je od svih pričesnika u uvodnoj sceni njezino lice jedino prikazano samo dijelom (iz profila), odnosno da je riječ o liku koji je izuzetno ambivalentan i složen, koji, za početak, podriva Thomasove groteskne predodžbe o Božjoj ljubavi, empatiji i sl. Radni dnevnici potkrepljuju to čitanje, npr. opisujući Thomasova previranja kao zaostala u vremenu u kojem je zapeo i on »ostarjeli školarac«:

»Jedan 'ja' odlazi u crkvu da bi pričao s Bogom... iz minulih stoljeća i generacija.« (Bergman 2018a: 108f)

U kontrastu s njim, Bergman je sam isticao kako je Marta (»nevjernik «) pravi protagonist drame ili pasije, dok Thomas (p)ostaje krut i nemoćan u susretu s njom i drugim pričesnicima, »ništavan, užasno sitna duša (cit. u Sjöman 1978: 46, 50f). Zaključnoj sekvenci filma, onoj mise održane za Martu koja jedina sjedi u publici, prethodi kadar najave koji pokazuje njezino lice dok zastaje gledajući pejzaž i moguće rute i zatim odlučno ulazi u crkvu, s Thomasom koji je slijedi u pozadini. Spomenuta scena nasilja, na primjer, obrće (ako je i postojala iluzija drukčijeg) odnos moći gdje Marta briše naočale i objašnjava Thomasu da ga zapravo i ne vidi, osim kao neku mutnu pojavu te ga sažalijeva. Ako je, drugim riječima, u radnom dnevniku stvoren film 
Pričesnici o »jednom ja u središtu«, dok se oko njega »ljudi materijaliziraju i nestaju « (cit. u Rossholm 2017:47), u tim istim tekstovima možemo pratiti kako se značenja uslojavaju zahvaljujući fluidnosti tog ega. Takvo tumačenje odgovara i sustavnijim čitanjima Bergmanovih zapisa kao radikalnijih od filmova i u prikazu ženskih likova koji su često provokativniji i očitije kompleksniji kako prerastaju u inkarnaciju »jastva « čije persone prelaze iz sporednih uloga u fokus priče (usp. Koskinen 2002: 49f).

Pred kraj poglavlja o radu na Pričesnicima, u radnom dnevniku Bergman daje naredbu samom sebi da mora naći identitet tom liku, »da se ne hrani samo mnome i figurom I.B.« (Bergman 2018a: 119). Taj identitet koji autor ili implicitni autor I. B. dijele s fiktivnim filmskim likovima distribuira se i $\mathrm{u}$ formi pisama i dnevnika, čestom pojavom u Bergmanovim filmovima. Pisani Bergmanovim rukopisom, ti fragmenti citiraju njegove radne dnevnike i druge tekstove. Takav je slučaj i s ljubavnim pismom Thomasu koje Marta čita naglas obraćajući se kameri, a isti je ustaljen bergmanovski postupak ponovila supruga umjetnika (Liv Ullmann) u Vučjem dobu (Vargtimmen, 1968.) i drugdje, sve do zaključne scene posljednjeg Bergmanova filma Saraband (2003). Saraband, naime, uokviruje scena u kojoj Ullmann, u još jednoj u nizu uloga pomoćnika u priči o umjetničkoj i obiteljskoj krizi, obraća kameri koristeći arhiv fragmenata poput fotografija iz Bergmanovih filmova, uključujući fotografije iz filma Saraband, čime joj je prema dijelu tumačenja konačno prepuštena uloga autora.

\section{U početku bijaše arhiv}

Sažimajući obrasce recepcije Bergmanovih filmova, Steene zaključuje kako su filozofska čitanja prevladavala, posebno u međunarodnim krugovima, još otkako je Andrew Sarris 1950-ih predstavio Bergmana američkoj publici kao "prvog istinski egzistencijalističkog filmaša u povijesti medija, redatelja koji je filmskom mediju dao metafizičku i etičku dimenziju« (Steene 2008: 215f). Bilo da su se tipično bavili egzistencijalizmom ili luteranizmom, ili dodavali poveznice s opskurnijim skandinavskim autorima, tu dominantu filozofskih čitanja među bergmanološkim studijama Steene naziva redukcionističkim. S jedne strane, sadržaj filmova bio im je zanimljiviji od filmskog stila koji je Bergman neprestano redefinirao, a s druge strane, autorica se, kao i niz suvremenih čitanja, pita zbog čega su antiintelektualne dimenzije filmskog medija koje je Bergman isticao od samog početka potpuno zanemarene.

»Ako uzmemo u obzir u kojoj je mjeri Bergman isticao važnost intuicije i emocionalnog impulsa u kreativnom procesu, u opreci prema intelektualnoj diskusiji i teoriji, ironično je da se toliko interpretacija fokusiralo na misaoni sadržaj njegova djela.« (Steene 2008: 222)

Do sličnog zaključka dolazi i Srđan Vučinić u eseju posvećenom Bergmanu i filozofiji umjetnosti:

»Bergmanovo shvaćanje filma u općim crtama možemo odrediti kao iracionalističko, emocionalističko i antiliterarno. (...) Za razliku od književnog teksta, koji prvo primamo kroz svjesni, razumski dio bića, film (kao i kazalište) po Bergmanu djeluje direktno na emocije, zaobilazeći svijest. Stoga u intervjuima on uporno zahtijeva od svojih poznanika da njegove filmove osjete, a ne da ih razumiju. Ovaj apel autora za otvorenošću pred iracionalnim i hipnotičkim svojstvima njegovih priča mahom je ostao neshvaćen (kako reče Wim Wenders, nema suvremenog redatelja koji je, poput Bergmana, u tolikoj mjeri propušten kroz filtere različitih 'mišljenja', teorija i analiza.« (Vučinić 2009: 46-47) 
Rijetki su primjeri emotivnih odgovora na Bergmanove filmove - poput Godardove Bergmanorame ${ }^{16}$ - pa će posebno recentne studije arhiva parafrazirati Bergmanove apele da se uvaže previđeni aspekti njegova rada. »Ja nisam nikakav analitičar, ja sam intuitivan« (Bergman 2018b: 30), a taj autobiografski lajtmotiv vezuje i za vlastitu profesiju: potrebu ili čak »bolest promatranja« i »predstavljanja« vlastitog ja (Koskinen 2002: 299-300). Stoga se ponavlja zaključak Marianne Höök, »do dan danas najpronicljivijeg među Bergmanovim biografima «, da je Bergmanov cijeli korpus niz repeticija na temu Bergman, odnosno »jedna velika ja-drama« (cit. u Holmberg 2018: 163) koja se provlači kroz prizore filmova i ostalih tekstova, kroz ogledala, persone, predstave, odnosno »autofikciju« arhiva u cjelini. Naglasak na fiktivnom i performativnom Bergmanovih autobiografskih materijala motivirao je i revizionistička čitanja njegova djela kao književnosti, ${ }^{17}$ no suvislije bi bilo govoriti o poetskoj ili umjetničkoj funkciji, odnosno o Bergmanovu arhivu ne samo u teorijski upućenom smislu proizvodnje značenja nego i kao umjetnosti.

U usporedbi sa sličnim autorskim arhivima, npr. Stanleyja Kubricka ili Carla Theodora Dreyera, Bergmanov je jedinstven po cjelovitosti korpusa, sačuvanih materijala posebno ranih stvaralačkih faza, uključujući npr. osobne bilješke i nacrte nastale prije tipkanih scenarija korištenih u produkciji. Da je riječ o pasioniranu arhivistu bilo je jasno i prije recentnih otkrića poput onog da je držao i mali hladnjak u ropotarnici, za okrepu u beskonačnim satima kopanja po vlastitoj prošlosti. Sam je Bergmanov način pisanja, uz neprestano vraćanje spomenutom repozitoriju slika i tekstova, arhivistički, iako je ta tendencija očitija u autobiografskim djelima kasnijih faza poput Fanny $i$ Alexander ili Slika.

Čitanje Bergmanove umjetnosti kao arhiva i Bergmanova arhiva kao umjetnosti može uputiti na ključne poetske crte toga korpusa: na fragmentarnost, preferiranje stvaralačkog procesa u odnosu na dovršeno djelo, vježbanje ruke, na isprepletenost autobiografskih i drugih fikcija, privatnog i javnog, različitih medija, tekstova, filmova, fotografija, slika itd. A Bergmanov zavidno dobro obrađen arhiv koje omogućuje fluidniji pristup fragmentima, bez kronološke ili druge uvriježene hijerarhije među verzijama tekstova, dodaje na mogućnosti bergmanovskog čitanja prema ranije previđenim uputama - vođenog npr. ritmom koji nalazi posvuda pa $\mathrm{i} »$ film pogađa naše emocije direktno, ne putem intelekta jer je film uglavnom ritam: to je udisanje i izdisanje $u$ kontinuiranom tijeku« ${ }^{18}$ (cit. u Singer 2009: 128)

\section{Literatura}

Ahndoril, Alexander. 2006. Regissören. Stockholm, Albert Bonnier Förlag.

Bergman, Ingmar. 1966. Filmska trilogija. Preveo Tomislav Ladan. Zagreb, Matica hrvatska.

Bergman, Ingmar. 1990. Moj život. Laterna magica. Preveo Mirko Rumac. Zagreb, Grafički zavod Hrvatske.

Bergman, Ingmar. 1996. Slike. Beograd, Jugoslovenska kinoteka.

Bergman, Ingmar. 2018a. Arbetsboken 1955-1974. Stockholm, Nortstedts.

Bergman, Ingmar. 2018b. Artiklar, essäer, föredrag. Stockholm, Nortstedts.

Burman, Christo. 2018. »Kommentar av Christo Burman«. Artiklar, essäer, föredrag. Stockholm, Nortstedts. Str. 299-303. 
Donner, Jörn. 2009. Bergman: PM. Stockholm, Ekerlids.

Flower, Dean. 1989. »Ingmar Bergman's Autobiography in Film«. The Hudson Review 42 (1989) 2. Str. 330-336. doi: https://doi.org/10.2307/3851538.

Godard, Jean-Luc. 1986. »Bergmanorama«. Godard on Godard. New York, Da Capo Press. Str. $75-80$.

Holmberg, Jan. 2018. Författaren Ingmar Bergman. Stockholm, Nortstedts.

Koskinen, Maaret. 2002. I begynnelsen var ordet: Ingmar Bergman och hans tidiga författarskap. Stockholm, Wahlström \& Widstrand.

Koskinen, Maaret. 2015. »Multiple Adaptation Processes: The case of Alexander Ahndoril's the Director and its Predecessors in Feature Film, Television, Documentary and Popular Print Media«. Journal of Scandinavian Cinema 5 (2015) 1. Str. 35-47. doi: https://doi.org/10.1386/jsca.5.1.35 1.

Koskinen, Maaret. 2010. The Silence: Pictures in the Typewriter, Writings on the Screen. Seattle, University of Washington Press.

Macnab, Geoffrey. 2009. Ingmar Bergman: The Life and Films of the Last Great European Director. London, I. B. Tauris.

Rossholm, Anna Sofia. 2017. Ingmar Bergman och den lekfula skriften. Göteeborg, Stockholm, Makadam förlag.

Simon, John. 1978. »Preface«. U: Sjöman, Vilgot. L136, diary with Ingmar Bergman. Preveo Alan Blair. Ann Arbor, Karoma Publishers. Str. vii-Xv.

Singer, Irving. 2009. Ingmar Bergman, Cinematic Philosopher: Reflections on His Creativity. Cambridge (MA), London, England, MIT press.

Sjöman, Vilgot. 1978. L136, diary with Ingmar Bergman. Preveo Alan Blair. Ann Arbor, Karoma Publishers.

Staiger, Janet. 2008. "Analysing Self-Fashioning in Authoring and Reception«. U: Koskinen, Maaret (ur.). Ingmar Bergman Revisited: Performance, Cinema and the Arts. London, Wallflower Press. Str. 89-106.

Steene, Birgitta. 2008. „A Professional Assessment: The Power of the Shadows or How We Study Ingmar Bergman«. U: Koskinen, Maaret (ur.). Ingmar Bergman Revisited: Performance, Cinema and the Arts. London, Wallflower Press. Str. 213-232.

Vučinić, Srđan. 2009. Rađanje kentaura: eseji o filmu i književnosti. Beograd, Arhipelag.

16

»Ingmar Bergman, intuitivan umjetnik, prezren od 'zanatlija', daje lekciju i najboljim scenaristima (...). Ljetna međuigra (Sommarlek, 1951.) je najljepši od svih filmova (...). Zašto? Zato što jednostavno jest. Samo film može dozvoliti takvo djetinje rezoniranje bez da se pravi da se srami. Zašto? Jer je to film (...). Divim se Viscontijevu filmu Bijele noći (Le notti bianche, 1957.), ali Ljetnu međuigru volim!« (Godard 1986: 80)

17

Iako Holmberg temeljito ilustrira npr. fikcionalizaciju ili jezične igre Bergmanovih intervjua, scenarija i drugih tekstova, pojam koji bi sažeo kvalitete koje opisuje je Jakobsonova poetska funkcija. S druge strane, njegova teza da je Bergman bolji književnik nego redatelj manje je uvjerljiva pa se čini se $\mathrm{i}$ da manje inzistira na njoj u recentnim istupima. Tvrdnja da je npr. Vučje doba nemoguć tekst za filmsku adaptaciju jer film ne može s tom lakoćom izraziti događaje koji su na granici objektivnog i subjektivnog, sna i jave, dodatno je problematična u Bergmanovu slučaju jer je riječ o autorovoj temeljnoj poetskoj crti, a koja se inspirirala onirizmom, fantastičnom i halucinatornom atmosferom klasika poput Fantomske kočije (Körkarlen, 1921.), Dreyerovim Vampirom (Vampyr, 1932.), vlastitim izvedbama Strindbergove Igre snova (Ett drömspel, 1902.), itd.

18

Slično zaključuje i Vučinić: »'Ritam je uvijek najvažniji zato što je ritam u svemu', kaže Bergman, tumačeći na taj način bolje od bilo kog kritičara i zapanjujuću kondenziranost radnje, emocija i značenja u najboljim svojim filmovima nastalim krajem pedesetih i polovinom šezdesetih godina prošlog stoljeća.« (Vučinić 2009: 47) 
Wood, Robin. 1979. Ingmar Bergman. London, Studio Vista.

Zern, Leif. 2018. Se Bergman. Stockholm, Natur \& Kultur.

\title{
Janica Tomić
}

\section{Reading Ingmar Bergman's Archive}

\begin{abstract}
Publically available since 2018, the Ingmar Bergman Archives gave rise to a wide range of readings and re-evaluations of primarily the written part of his oeuvre. While considering the relation between Bergman's manuscripts and films, the paper points out the significance of his workbooks (1938 - 2006) and other textual fragments for understanding the Archives as a work of art. The concluding analysis of the film Winter Light (Nattvardsgästerna) illustrates how the intertwined parts of the Archives contribute to understanding its appeal throughout the history of readings. By highlighting the previously neglected affective layers of the film, the paper also builds on hypotheses about the need to expand on existing philosophical and theoretical approaches to Bergman's work.
\end{abstract}

\section{Keywords}

Ingmar Bergman, archive, workbooks, Winter Light, Nattvardsgästerna 